DOI: $10.20472 / E S .2020 .9 .1 .008$

\title{
THE RELATION BETWEEN CLIMATE CHANGE AND ECONOMIC GROWTH: THE IN-VESTIGATION THE REGIONAL DIFFERENCES WITH RCM MODEL IN EU-28 COUNTRIES
}

\section{AYNUR PALA}

\begin{abstract}
:
This study investigates the effect of climate change on economic growth. In the study, it has been used over the period from 1996 to 2014 for EU-28 countries. We applied endogeneity, cross-sectional dependence and slope homogeneity tests. Then, we used panel unit-root and panel cointegration tests. Estimated random coefficient panel regression results show that increasing carbon emission contributes to economic growth in North and East Europe regions countries, relatively cold side. In South-West Europe countries, coefficient of $\mathrm{CO} 2$ is insignificant. Increasing carbon emission positively effect on economic growth through especially agricultural and tourism sector outputs in North and East Europe regions.
\end{abstract}

\section{Keywords:}

Carbon emission, Economic Growth, Random Coefficient Model

JEL Classification: Q50, 040, C33

\section{Authors:}

AYNUR PALA, Okan Üniversitesi, Turkey, Email: aynur.pala@okan.edu.tr

\section{Citation:}

AYNUR PALA (2020). The Relation between Climate Change and Economic Growth: The In-vestigation The Regional Differences with RCM Model in EU-28 Countries. International Journal of Economic Sciences, Vol. IX(1), pp. 135-155., 10.20472/ES.2020.9.1.008 


\section{Introduction}

Climate change means an increase in average surface temperatures caused by increasing greenhouse gases. Increasing greenhouse gases cause climate change. (Pachauri and Reisinger, 2007) In 2015, world carbon dioxide (CO2) emissions constitute $72 \%$ of emitted greenhouse gases. Carbon dioxide emissions are the most important factor of climate change. (Tumlin, 2012). There is positive and significant correlation between carbon emission and temperature (Lee, 2016)

In 2017, share in global GDP of the European Union is $16.52 \%$.Carbon emission, one of the most important indicators of climate change, represents about $10 \%$ of total global emissions in EU. According to the International Energy Agency (IEA), global carbon emissions grew by $1.4 \%$ in 2017. World GDP grew by $3.9 \%$ in 2017 . EU is the world's secondlargest economy according to GDP, generating 19.2 trillion dollars that is $\% 16.52$ share of the world's GDP in 2017. Eurostat estimates that in 2017, CO2 emissions increased by $1.8 \%$ compared with the previous year. The share of the European Union in global total $\mathrm{CO} 2$ emissions remained at $9.6 \%$ in 2016.

There are many effects of climate change on economic growth: negative and positive. Some of the negative aspects of climate change include loss of land and forest area, water supplies, increased energy demand for cooling, loss of agricultural output, decreasing tourism sector income. Some positive outcomes of climate change include increased agricultural production, lower heating costs, transport infrastructure, tourism resorts, insurance and health sector.

Climate change affected differently on regions and sectors in Europe (Kondrup, 2017). The effect of climate change differs between sectors in Europe, there are differences between Northern and Southern Europe regions (Jacop et al, 2017). Climate change will affect different regions of the world, in the agricultural sector (Parry et al, 2004) The effect of climate change will be different in the vary regions of Europe, with increasing yields in Northern regions, and yield decreases in Southern regions. The Southern Europe will experience negative developments for agriculture sector (Kelemen, 2009) 
Ciscar (2009) proved that Southern Europe is sensitive region to climate change. However, Northern Europe has positive effects in agriculture. In Southern Europe, the crop yields decreased over the period 1976-2005 due to temperature change. In Northern-Central Europe, the yield has increased since 1976, linked to the climate change. It is observed losing yield in Southern Europe and increasing yield in Northern Europe (Chloupek et al, 2004). Behrens (2010) found that impact of global climate change on agriculture sector will be vary in the Northern, Southern and Eastern Europe. Northern Europe may positively affected by climate change, but Southern Europe may negatively affected. In Northern Europe, farming has no sensitive to climate change. Agriculture in Northern European will be positively affected from higher temperatures. In Northern Europe countries, productivity could increase $40-50 \%$ by the 2080 s. (Ciscar, 2009)

In Europe, tourism is an important sector. Climate change may effect on tourist flows. In the Fourth Assessment Report of the IPCC, climate change will affect tourism in many different ways. Amelung and Moreno (2012) showed that Southern Europe countries will less affirmative to tourism, while Northern Europe countries will better, than climate change. Northern Europe region may gain from warmer temperatures while the Southern Europe region will be droughts, in summer. (Behrens, 2010)

Our research aims to analyse the impact of carbon emissions on economic growth and to determine regional differences with random coefficient model (RCM) in EU-28 countries over the period 1996-2013.

\section{Literature Review}

There are many researches, has not any consensus, on the linkage between economic growth and carbon emission using by Granger causality for one country and countries. (Zhang and Cheng (2009), Soytas and Sarı (2009), Halicioglu (2009), Chang (2010), Tiwari (2011), Pao and Tsai (2011), Xue et al. (2014), Magazzino (2016), Wang et al (2016))

Zhang and Cheng (2009) examined the linkage among economic growth, energy consumption and carbon emissions applying Granger causality over the period 1960-2007 in China. The study shows that carbon emissions and energy consumption has no effect on economic growth. Chang (2010) 
researched the link between carbon emissions, energy consumption and economic growth with Granger causality over the period 1981-2006 in China. The study showed bi-directional causality running from GDP to carbon emissions. Tiwari (2011) analyzed the causality among energy consumption, $\mathrm{CO} 2$ emissions and economic growth using Granger causality in India. The results of the study indicate that carbon emission has negatively affect on economic growth. Pao and Tsai (2011) examined the link between carbon emissions, energy consumption and economic growth using the Grey prediction model (GM) for the period of 1980-2007 in Brazil. The consequences of the study show that there is a bi-directional causality among income, energy consumption and carbon emissions. Magazzino (2016) investigated the link among CO2 emissions, energy consumption and economic growth by using VAR over the period 1970-2006 in Italy. The results of Toda and Yamamoto Granger non-causality test show that there are bi-directional causality between carbon emissions and economic growth.

Climate change effects on country's economy. Furthermore, climate change has a heterogeneous effects within countries. (O'Brien, Sygna and Haugen, 2004; Parry et al., 2007; Lucas and Simone, 2011). Temperature and precipitation are important inputs in agriculture sector, so that the widely effects of climate change will be on agriculture. (Cooper, 2000; Parry and others, 2007). Gregory, Ingram and Brklacich (2005) suggested that climate change is important for agriculture, but its differencied among regions. Mendelsohn and Dinar (1999) proved that increasing temperatures has been negatively impacted on grain yields. Mendelsohn, Dinar and Sanghi (2001) and Mendelsohn and Williams (2004) present that climate change will positively impact cool areas and negatively affect hot areas. Bozkurt and Akan (2014) studied the relationships between economic growth, CO2 emissions and energy consumption using by VECM in Turkey for the period 1960-2010. They found that carbon emissions have negatively impact on economic growth. Stolyarova (2009) analyzed the relationship between carbon emissions and economic growth using the Hierarchical Clustering on Principal Components (HCPC) in 93-countries for the period 1960-2008. They show that carbon emissions positively determined by GDP. Omri (2013) investigated the link between energy consumption, carbon 
emissions and economic growth using simultaneous equation model over the period of 1990-2011. They revealed that carbon emissions negatively effect on economic growth. Brown et al (2005) examined link between climate variables and economic growth using data for 180 nations. This study showed that precipitation negatively effect on economic growth. Mulatu et al. (2016) investigated carbon emissions effect on agricultural productivity and household welfare using Computable General Equilibrium (CGE) model. The results show carbon emissions negatively effect on agricultural productivity and household welfare.

There are two lines of empirical literature in environmental economics: the environmental Kuznets curve (EKC) hypothesis and environmental convergence.

The EKC states that environmental deterioration increases with income until a turning point after which it decreases for higher levels of income. Nasir and Rehman (2011) and Hassan et al. (2015), Narayan and Narayan (2010), Alam et al. (2016) found that inverted U-shaped curve the link between $\mathrm{CO} 2$ emission and economic growth. These results supported EKC hypothesis. Hassan et al. (2015) investigated the main factors impacting carbon dioxide emissions pattern from economic growth, inequality and poverty in Pakistan using panel error correction model. Findings showed that EKC hypothesis is supported in Pakistan. Narayan and Narayan (2010) investigated that whether the EKC hypothesis is valid in 43 developing countries. They found that EKC is supported in these countries. Alam et al. (2016) examined the nexus among carbon dioxide emission, economic growth, energy consumption and population growth in Brasil, China, India and Indonesia using linear and quadratic ARDL error correction model. They found evidence EKC hypothesis is valid for Brasil, China and Indonesia. Apergis and Ozturk (2015) studies did not supported inverted-U shaped. Apergis and Ozturk (2015) tested EKC hypothesis for 14 Asian countries and they found that the support of the EKC hypothesis. Mir and Storm (2016) assess EKC hypothesis using production and consumption based carbon dioxide emissions per capita and GDP per capita in forty-countries. As a result of linear, quadratic and cubic fixed effect panel regression model, they found that monotonically increasing relation between per capita GDP and carbon dioxide emissions. 
Environmental convergence has been a rich subject following economic growth literature. Convergence theory is referred to "catch-up effect." Environmental convergence occurs if countries with low emissions of pollutants per capita increase their level of emissions, while the opposite applies to high emissions countries. Researchers have recently extended that work by focusing on the environmental convergence hypothesis, a concept taken from the economic growth literature (Strazicich and List (2003), Brock and Taylor (2010), Nguyen-Van (2005), Miketa and Mulder (2005), Mulder and de Groot (2007), Criado et al. (2011)). Strazicich and List (2003) examine the convergence properties of carbon emissions over a panel dataset of 21 industrial countries from 1960 to 1997. They find evidence that carbon emissions patterns have converged. Brock and Taylor (2010) investigated the EKC with modified approach and connect the EKC to Solow model using CO2 data in 173 countries for the period of 19601998. They use the beta convergence approach and find statistically significant convergence across 165 countries between 1960 and 1998. Nguyen Van (2005) finds no convergence in per capita CO2 in developed and developing countries. Miketa and Mulder (2005) analyzed energyproductivity convergence (the inverse of energy intensity) across 56 developed and developing countries in 10 manufacturing sectors, and found that crosscountry differences tended to decline, particularly in less energy-intensive sectors. Mulder and De Groot (2007), also considering the OECD, but with a greater degree of sectoral disaggregation, found that, for most of the 14 economic sectors they considered, lagging countries tended to catch up with technological leaders in energy productivity. Criado et al. (2011) proved that pollution rises rapidly in faster growing economies. But there is convergence so tahat countries with higher levels of pollution are more likely to reduce pollution faster than countries with low levels of pollution.

\section{Data and Methodology}

\section{Data}

The aim of the study is to investigate the impact of climate change on economic growth following basic production function, $y=f(K, L)$ in $E U-28$ countries. EU-28 countries includes Austria, Belgium, Bulgaria, Croatia, 
Republic of Cyprus, Czechia, Denmark, Estonia, inland, France, Germany, Greece, Hungary, Ireland, Italy, Latvia, Lithuania, Luxembourg, Malta, Netherlands, Poland, Portugal, Romania, Slovakia, Slovenia, Spain, Sweden and the UK.

It has been specified regions, where countries belong, to investigate whether there are different effects of $\mathrm{CO} 2$ emission on economic growth between regions in the EU-28 countries. Northern and Eastern Europe Countries include Bulgaria, Czechia, Hungary, Poland, Romania, Slovakia, Denmark, Estonia, Finland, Ireland, Latvia, Lithuania, Sweden and United Kingdom. Southern and Western Europe Countries covers Austria, Belgium, Croatia, Republic of Cyprus, France, Germany, Greece, Italy, Luxembourg, Malta, Netherlands, Portugal, Spain. Dataset covers the period 1996-2013. We used GDP growth (\%), gross fixed capital formation, labor force participation rate, carbon dioxide emissions (metric ton per capita) variables and data is collected from World Bank.

In works about climate change, selecting proxy variables is very important. GHG emission levels, atmospheric GHG concentration levels, global mean temperature, sea-level rise and intensity of extreme events are the most generally used proxies. In the study, carbon emission was selected as a proxy of the climate change. Because, as shown in the Graph 1, CO2 emission has strong positive relation with surface temperature and there are many studies which has used $\mathrm{CO} 2$ emission proxy as a climate change. Lee (2016) show that there is positive relation past atmospheric CO2 concentrations and reconstructed temperatures. (Potter, 1995; Parry et al., 2007; Dell et al, 2008). 
Figure 1. Average $\mathrm{CO} 2$ Emission and Global Surface Temperature

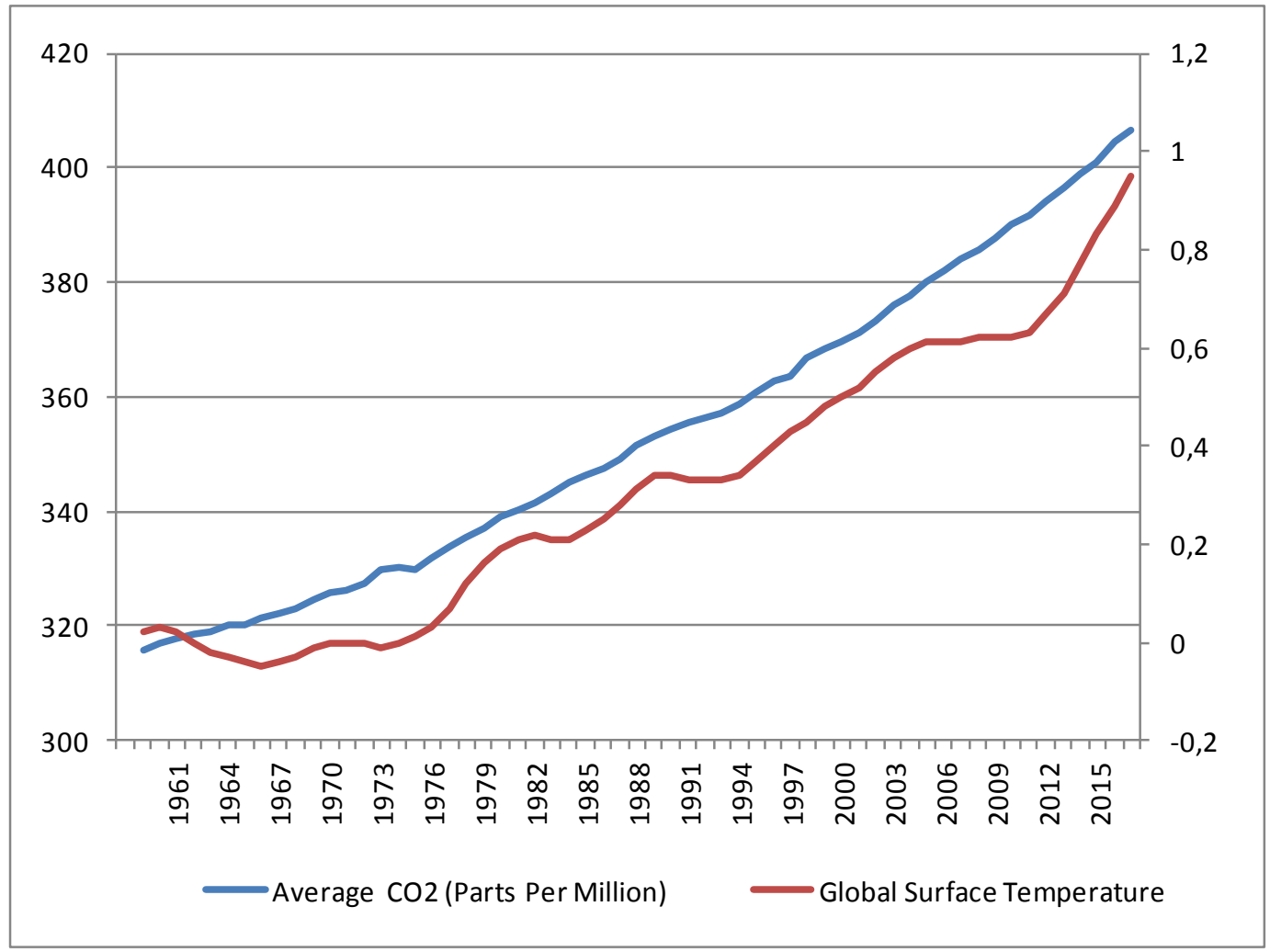

Source: NASA

Table 1. Descriptive Statistics

\begin{tabular}{lcccc}
\hline Variables & Mean & $\begin{array}{c}\text { Standard } \\
\text { Deviation }\end{array}$ & Maximum & Minimum \\
\hline GDPG & 2.513 & 3.618 & -17.950 & 12.230 \\
\hline GCF & 22.435 & 4.077 & 5.390 & 37.100 \\
\hline LFPR & 69.403 & 5.490 & 57.500 & 80.900 \\
\hline CO2 & 8.391 & 3.887 & 2.682 & 24.824 \\
\hline
\end{tabular}

Source: calculated by author. 


\section{Methodology}

The study follows basic production function, $y=f(K, L)$

We added carbon dioxide emission proxy for climate change.

$$
G D P G_{i t}=\alpha_{i t}+\beta_{0 i t} G C F_{i t}+\beta_{1 i t} L F P R_{i t}+\beta_{2 i t} C O 2_{i t}+\varepsilon_{i t}(1)
$$

where $\mathrm{t}=1, \ldots 14$ time period; $\mathrm{i}=1, \ldots, 28 \mathrm{EU}$ countries, GDPG, GDP Growth (\%); GCF, Gross Fixed Capital Formation; LFPR, Labor Force Participation Rate; $\mathrm{CO} 2$ and Carbon Dioxide Emissions (metric ton per capita).

\section{Results}

Firstly, it will determined whether endogeneity, cross-sectional dependence and slope homogeneity.

\section{Durbin-Wu-Hausman Endogeneity test}

The Durbin-Wu-Hausman test was used to test the endogeneity. (Chi2(1) $=12.865$, P-Value $=0.000$ ). The null hypothesis of "no endogeneity" was rejected, suggesting that the ordinary least squares estimates might be biased and inconsistent. When the methodological issue is the endogeneity of variable $\mathrm{X}$, then a standard econometric method includes the econometric instrumental-variable (IV) method for linear regression. However, we will not use that method. The method makes a much stronger assumption than the RCM.

\section{Cross-sectional Dependency Tests}

In the study, when $T<\mathrm{N}$, Pesaran's (2004) CD, Friedman's (1937) and Frees' (1995) statistics will used. Pesaran (2004) cross-sectional dependence (CD) test, as follows,

$$
C D=\sqrt{\frac{2 T}{N(N-1)}}\left(\sum_{i=1}^{N-1} \sum_{j=i+1}^{N} \rho_{i j}\right)
$$


Friedman (1937) statistic, as follows,

$$
R_{\text {average }}=\frac{2}{N(N-1)} \sum_{i=1}^{N-1} \sum_{j=i+1}^{N} r_{i j}
$$

Frees' $(1995,2004)$ statistic is given by

$$
R_{\text {average }}^{2}=\frac{2}{N(N-1)} \sum_{i=1}^{N-1} \sum_{j=i+1}^{N} r_{i j}^{2}
$$

Table 2 gives Pesaran CD, Frees' and Friedman's test statistics. The results represent the null hypothesis of cross-sectional independence is rejected. Findings require using panel unit-root tests, considered crosssection dependence.

Table 2. Cross-sectional Dependency Tests

\begin{tabular}{lccc}
\hline \multicolumn{1}{c}{ Model } & Pesaran (2004) & Frees (1995) & Friedman (1937) \\
\hline Fixed Effect & $45.801^{* * *}(0.000)$ & $4.573^{* * *}$ & $204.737^{* * *}$ \\
\hline Random Effect & $46.097^{* * *}(0.000)$ & $4.569^{* * *}$ & $204.768^{* * *}$ \\
\hline
\end{tabular}

Note: The $p$-values are in parentheses. ${ }^{* * *},{ }^{* *}$, and ${ }^{*}$ are the significance for at $1 \%, 5 \%$ and $10 \%$ levels.

\section{Slope Homogeneity Test}

Slope homogeneity test, to determine of whether slope coefficients of the cointegration equation are homogeneous, developed by Swamy (1970). Pesaran and Yamagata (2018) improved Swamy's slope homogeneity test and formed two test statistics; $\widetilde{\Delta}$ and $\tilde{\Delta}_{a d j}$.

$$
\begin{gathered}
\tilde{\Delta}=\sqrt{N}\left(\frac{N^{-1} \bar{S}-k}{\sqrt{2 k}}\right) \sim X_{k}^{2}(\text { for large sample })(3) \\
\tilde{\Delta}_{a d j}=\sqrt{N}\left(\frac{N^{-1} \bar{S}-k}{v(T, k)}\right) \sim N(0,1)(\text { for small sample) }(4)
\end{gathered}
$$

$\mathrm{N}$ denotes number of cross-section unit; $\mathrm{S}$ denotes the Swamy test statistic; $k$ denotes independent variables. If $p$ value of the test is larger than $5 \%$, the 
null hypothesis is accepted at a $5 \%$ significance level and the cointegrating coefficients are considered homogenous.

We test the hypothesis of slope homogeneity using the test developed by Pesaran and Yamagata (2008). The result of test is showed in Table 1. The test reject the null hypothesis of the slope homogeneity. The null hypothesis of slope homogeneity is can be rejected because the probability values bigger than 0.05. This is the evidence of slope coefficients are heterogeneous. Heterogeneous exists across EU-28 countries; we should employ heterogeneous panel data models. The Random Coefficient Model $(\mathrm{RCM})$ is suitable heterogeneous panel.

Table 2. Pesaran and Yamagata (2008) Slope Homogeneity Tests

\begin{tabular}{|c|c|c|}
\hline Slone Homogeneitv & $\Delta$ statistic & P value \\
\hline$\tilde{\Lambda}$ test & 0.953 & 0.184 \\
\hline$\tilde{\Delta}_{a d i}$ test & 0.431 & 0.457 \\
\hline
\end{tabular}

Note: ${ }^{* *},{ }^{* *}$, and ${ }^{*}$ are the significance for at $1 \%, 5 \%$ and $10 \%$ levels.

\section{Pesaran $(2003,2005)$ CADF Panel Unit-Root Test}

We used the second-generation panel unit-root test of Pesaran (2003, 2005). Cointegrated Augmented Dickey Fuller (CADF) test take into consideration the cross-sectional dependence. Table 3 shows the results of CADF test. As a result of test, the null hypothesis of unit root is rejected and all variables are I(1).

Table 3. Pesaran $(2003,2005)$ CADF Panel Unit-Root Test

\begin{tabular}{lll}
\hline Variables & $t$-bar & $Z$ ( $p$ value) \\
\hline Level & & \\
\hline GDPG & -1.718 & $0.115(0.546)$ \\
\hline GCF & -1.332 & $2.116(0.983)$ \\
\hline LFPR & -1.505 & $1.220(0.889)$ \\
\hline CO2 & -1.230 & $2.644(0.996)$ \\
\hline First Difference & & \\
\hline DGDPG & -2.112 & $-1.928^{* *}(0.027)$ \\
\hline
\end{tabular}




\begin{tabular}{lll}
\hline DGCF & -2.613 & $-4.530^{\star * *}(0.000)$ \\
\hline DLFPR & -2.461 & $-3.738^{\star * *}(0.000)$ \\
\hline DCO2 & -2.716 & $-5.065^{\star \star *}(0.000)$ \\
\hline
\end{tabular}

Note: The critical values for t-bar \%1 $\left(^{* * *}\right), \% 5\left(^{* *}\right)$ and $\% 10\left(^{*}\right)$ for meaning level respectively $-2.32,-2.15$ and -2.07 . The critical values for $Z$ test statistics $\% 1, \% 5$ and $\% 10$ for significance level respectively $-2.326,-1.645$ and -1.282 .

Westerlund (2007) cointegration test, which allows cross-sectional dependence, are used. Table 4 include the result of Westerlund (2007) cointegration test for the EU-28 panel. The null hypothesis of no cointegration is rejected. Therefore, all variables are cointegrated.

\section{Table 4. Westerlund (2007) Panel Cointegration Test}

\begin{tabular}{lcc}
\hline Statistics & Value & $Z$ \\
\hline$G_{\tau}$ & -2.950 & $-2.651^{* * *}(0.004)$ \\
\hline$G_{\alpha}$ & -5.204 & $6.084(1.000)$ \\
\hline$P_{\tau}$ & -13.658 & $-1.721^{* * \star}(0.043)$ \\
\hline$P_{\alpha}$ & -5.168 & $4.164(1.000)$ \\
\hline
\end{tabular}

Note: $G_{\tau}$ and $G_{\alpha}$ are group mean statistics; $\mathrm{P}_{\tau}$ and $\mathrm{P}_{\alpha}$ are panel test statistics. ${ }^{* *},{ }^{* *}$, and ${ }^{*}$ are the significance for at $1 \%, 5 \%$ and $10 \%$ levels.

The results of random coefficient model (RCM) is presented in Table 5. Coefficient of capital formation is positive and significant for Estonia, Finland, Germany, Greece, Latvia, Lithuania, Netherlands, Portugal, Romania, Spain, United Kingdom and insignificant for the other EU countries. The coefficient of labor force is negative and significant only for Latvia and United Kingdom. Results are consistent with the Omri (2013) and Shahbaz et al. (2012) studies. They suggest that capital has a positive impact on economic growth, while labor force has a negative impact. Negative impact of labor force on economic growth in Latvia and United Kingdom may be due to low productivity of labor force. 
Table 5. The Estimation of RCM Model (Dependent Variable: Economic Growth)

\begin{tabular}{|c|c|c|c|c|}
\hline & DCO2 & DLFPR & DGFCF & Intercept \\
\hline EU-28 & $2.264^{*}(0.006)$ & $-0.412(0.148)$ & $0.494^{*}(0.004)$ & $0.197(0.245)$ \\
\hline \multicolumn{5}{|c|}{ Northern and Eastern Europe EU-28 Countries } \\
\hline Bulgaria & $4.429 *(0.015)$ & $-0.713(0.192)$ & $0.179(0.556)$ & $0.298(0.198)$ \\
\hline Czechia & $1.980(0.120)$ & $-0.311(0.520)$ & $0.595(0.090)$ & $0.213(0.374)$ \\
\hline Estonia & $2.540^{*}(0.028)$ & $-0.747(0.138)$ & $0.712^{*}(0.032)$ & $0.237(0.260)$ \\
\hline Finland & $1.753^{*}(0.021)$ & $-0.394(0.409)$ & $0.831 *(0.011)$ & $0.183(0.425)$ \\
\hline Hungary & $4.683^{*}(0.015)$ & $-0.593(0.269)$ & $0.132(0.705)$ & $0.398(0.097)$ \\
\hline Ireland & $0.458(0.794)$ & $-0.397(0.436)$ & $0.384(0.237)$ & $0.074(0.737)$ \\
\hline Latvia & $5.818^{*}(0.002)$ & $-1.329^{*}(0.014)$ & $0.658^{*}(0.041)$ & $0.478^{*}(0.033)$ \\
\hline Lithuania & $4.674^{\star}(0.008)$ & $-0.238(0.655)$ & $0.785^{\star}(0.02)$ & $0.252(0.266)$ \\
\hline Poland & $3.510^{*}(0.002)$ & $-0.706(0.140)$ & $0.365(0.123)$ & $0.165(0.504)$ \\
\hline Slovak Rep. & $3.990^{*}(0.038)$ & $-0.484(0.288)$ & $0.365(0.245)$ & $0.267(0.266)$ \\
\hline Slovenia & $3.751^{*}(0.042)$ & $-0.321(0.556)$ & $0.372(0.291)$ & $0.193(0.422)$ \\
\hline Sweden & $4.294^{*}(0.007)$ & $-0.677(0.184)$ & $0.449(0.186)$ & $0.341(0.166)$ \\
\hline U. Kingdom & $3.098^{*}(0.011)$ & $-1.072^{*}(0.038)$ & $0.850^{*}(0.018)$ & $0.444(0.092)$ \\
\hline \multicolumn{5}{|c|}{ Southern and Western Europe Countries } \\
\hline Austria & $-0.726(0.569)$ & $-0.440(0.412)$ & $0.364(0.305)$ & $0.089(0.717)$ \\
\hline Belgium & $1.083(0.315)$ & $0.822(0.090)$ & $0.321(0.376)$ & $-0.093(0.715)$ \\
\hline Croatia & $2.350(0.219)$ & $-0.289(0.57)$ & $0.106(0.757)$ & $0.062(0.800)$ \\
\hline Cyprus & $1.805(0.146)$ & $-0.102(0.800)$ & $0.225(0.515)$ & $0.011(0.963)$ \\
\hline France & $1.194(0.504)$ & $-0.639(0.217)$ & $0.635(0.077)$ & $0.140(0.595)$ \\
\hline Germany & $4.606^{\star \star \star}(0.007)$ & $-0.097(0.848)$ & $0.802^{*}(0.021)$ & $0.322(0.177)$ \\
\hline Greece & $-0.361(0.826)$ & $-0.176(0.737)$ & $0.542^{*}(0.05)$ & $0.0521(0.828)$ \\
\hline Italy & $4.109^{*}(0.010)$ & $-0.755(0.160)$ & $0.431(0.151)$ & $0.384(0.131)$ \\
\hline Luxembourg & $0.768(0.378)$ & $-0.355(0.489)$ & $-0.061(0.863)$ & $0.118(0.584)$ \\
\hline Malta & $-0.857(0.561)$ & $0.021(0.966)$ & $0.441(0.194)$ & $0.026(0.908)$ \\
\hline Netherlands & $2.128(0.105)$ & $-0.841(0.070)$ & $0.935^{\star}(0.009)$ & $0.417(0.091)$ \\
\hline Portugal & $-0.644(0.655)$ & $-0.292(0.557)$ & $0.700 *(0.031)$ & $0.107(0.646)$ \\
\hline Romania & $2.436(0.179)$ & $-0.086(0.871)$ & $0.663^{*}(0.048)$ & $0.160(0.473)$ \\
\hline Spain & $-0.090(0.943)$ & $-0.342(0.416)$ & $0.673^{*}(0.024)$ & $0.127(0.612)$ \\
\hline
\end{tabular}

Note: ${ }^{* *},{ }^{* *}$, and ${ }^{*}$ are the significance for at $1 \%, 5 \%$ and $10 \%$ levels.

Results show carbon emissions positively impact on economic growth in Northern and Eastern Europe Countries, included Bulgaria, Estonia, Finland, Hungary, Latvia, Lithuania, Poland, Slovak Republic, Slovenia and Sweden, United Kingdom and in only two Southern and Western Europe 
countries, Germany and Italy. Carbon emissions have no significant impact on economic growth in Southern and Western Europe countries excluded Italy and Germany; namely, Austria, Belgium, Croatia, Republic of Cyprus, France, Greece, Luxembourg, Malta, Netherlands, Portugal, Romania, Spain.

\section{Conclusion}

This paper aims to investigate the effect of climate change (carbon emission proxy) on economic growth for EU 28 countries, over the period 1996-2015 for EU-28 countries using by random coefficient panel data model. For this purpose, we applied endogeneity, cross-sectional dependence, slope homogeneity, panel unit-root and panel cointegration test. Then, we used random coefficient model (RCM) to estimation. Panel regression results show that coefficient of carbon emissions and capital formation are positive and significant and coefficient of labor force is statistically insignificant. Results show that carbon emission has a positive significant effect on economic growth in Northern and Eastern Europe EU28 countries. This relation is insignificant in Southern and Western Europe EU-28 countries. This result supported by Mendelsohn, Dinar and Sanghi (2001) and Mendelsohn and Williams (2004), O'Brien, Sygna and Haugen (2004), Parry and others (2007), Lucas and Simone (2011), Gregory, Ingram and Brklacich (2005). Consequently, the effect of climate change on economic growth is different between North (cold) - South (hot) countries. It is imported that consider this different effect of climate change on economic growth in future related works. 


\section{References}

Alam, M.M. Murad, M.W. Noman, A.H.M. and Ozturk, I. (2016) Relationships among carbon emissions, economic growth, energy consumption and population growth: testing Environmental Kuznets Curve hypothesis for Brazil, China, India and Indonesia, Ecological Indicators, 70, 466-479. https://doi.org/10.1016/j.ecolind.2016.06.043

Amelung B, Moreno A. 2012. Costing the impact of climate changein tourism in Europe: results of the PESETA project. Climate Change, 112(1), 83-100. https://doi.org/10.1007/s10584-011-0341-0

Apergis, N., Ozturk, I. (2015), Testing environmental kuznets hypothesis in Asian countries. Ecological Indicators, 52, 16-22. https://doi.org/10.1016/j.ecolind.2014.11.026

BEHRENS, A.; GEORGIEV, A.; CARRARO, M. (2010), Future Impacts of Climate Change across Europe, Center for European Policy Studies (CEPS) Working Document No. 324, Brussels.

BOZKURT, Cuma; AKAN, Yusuf (2014), Economic Growth, CO2 Emissions and Energy Consumption: The Turkish Case, International Journal of Energy Economics and Policy, Vol.4, No.3, 484-494.

Brock, William A., Taylor, M. Scott, 2010. The green Solow model. Journal of Economic Growth 15, 127-153. https://doi.org/10.1007/s10887-0109051-0

Brown, C., Meeks, R. Ghile, Y. and Hunu, K. (2005), An empirical analysis of the effects of climate variables on national level economic growth, Policy Research Working Paper 5357, World Bank.

BREUSCH, Trevor Stanley; PAGAN, Adrian Rodney (1980), The Lagrange Multiplier Test and its Applications to Model Specification in Econometrics, The Review of Economic Studies, Vol.47, No.1, 239253. https://doi.org/10.2307/2297111

CHANG, C-C. (2010) A multivariate causality test of carbon dioxide emissions, energy consumption and economic growth in China, Applied Energy, Vol.87, 3533-3537. https://doi.org/10.1016/j.apenergy.2010.05.004 
CHLOUPEK, Oldřich; HRSTKOVA, P.; SCHWEIGERT, Peter (2004), Yield and its stability, crop diversity, adaptability and response to climate change, weather and fertilisation over 75 years in the Czech Republic in comparison to some European countries, Field Crop Research, Vol.85, No.2, 167-190. https://doi.org/10.1016/S03784290(03)00162-X

CISCAR, Juan-Carlos, (2009), Climate change impacts in Europe: Final Report of the PESETA Research Project, JRC Scientific and Technical Reports.

Cooper, R.N. (2000), International Approaches to Global Climate Change, The World Bank Research Observer, 76648, 15(2), 145-72. https://doi.org/10.1093/wbro/15.2.145

Ordás Criado, C., Valente, S. and Stengos, T. (2011) Growth and pollution convergence: Theory and evidence, Journal of Environmental Economics and Management, 62(2), 199-214. https://doi.org/10.1016/j.jeem.2010.10.009

De HOYOS, R. E.; SARAFIDIS, V. (2006), Testing for cross-sectional dependence in panel-data models, Stata Journal, Vol.6, No.4, 482496. https://doi.org/10.1177/1536867X0600600403

DELL, Melissa; JONES, Benjamin F.; OLKEN, Benjamin A. (2008), Climate Change And Economic Growth: Evidence From The Last Half Century, NBER Working Paper Series, Working Paper 14132. https://doi.org/10.3386/w14132

Mendelsohn, R., Dinar, A. and Sanghi, A. (2001) The effect of development on the climate sensitivity of agriculture. Environment and Development Economic. 6, 85-101. https://doi.org/10.1017/S1355770X01000055

Gregory, P.J., Ingram, J.S.I. and Brklacich, M. (2005) Climate Change and Food Security. Philosophical Transactions of the Royal Society B, 360, 2139-2148. https://doi.org/10.1098/rstb.2005.1745

Halicioglu F., (2009), An econometric study of CO2 emissions, energy consumption, income and foreign trade in Turkey, Energy Policy, 37, 11561164. https://doi.org/10.1016/j.enpol.2008.11.012 
Hassan, S.A., Zaman, K. and Gul, S. (2015) The Relationship between Growth-Inequality-Poverty Triangle and Environmental Degradation: Unveiling the Reality, Arab Economic and Business Journal, 10(1), 57-71. https://doi.org/10.1016/j.aebj.2014.05.007

JACOB, D.; KOTOVA, L.; TEICHMANN, C.; SOBOLOWSKI, S.P.; VAUTARD, R.; DONNELLY, C.; KOUTROULIS, A.G.; GRILLAKIS, M.G..; TSANIS, I.K.; DAMM, A.; SAKALLI, A., VLIET, M.T.H. (2018), Climate Impacts in Europe Under $+1.5 \mathrm{C}$ Climate change, Earth's Future, Vol.6, 264-285. https://doi.org/10.1002/2017EF000710

KELEMEN, Agnes; MUNCH, Wolfgang; POELMAN, Hugo; GAKOVA, Zuzana; DIJKSTRA, Lewis; TORIGHELLI, Beatriz, (2009), Regions 2020 the Climate Change Challenge for European Regions, European Commission Directorate-General Regional Policy, Policy Development.

KONDRUP, Claus, (2017), Eu's Role in Ensuring Climate Adaptation and A Resilient Europe, DG Climate Action, Adaptation unit EFCA Conference: Global challenges - sustainable solutions and the role of cities, companies and consultants Copenhagen.

LEE, H. (2016), Analysis of Carbon Dioxide and Cloud Effects on Temperature in Northeast China, Information Technology and Quantitative $\begin{array}{llll}\text { Management } & \text { (ITQM), } & \text { 690-699. }\end{array}$ https://doi.org/10.1016/j.procs.2016.07.172

Lucas, B. and Simone, V. (2011) Climate Change and Uneven Development, Scandinavian Journal of Economics, 113 (4), 825-845. https://doi.org/10.1111/j.1467-9442.2011.01676.x

MAGAZZINO, Cosimo, (2016), The relationship between CO2 emissions, energy consumption and economic growth in Italy, International Journal of Sustainable Energy, Vol.35, No.9, 844-857. https://doi.org/10.1080/14786451.2014.953160

Mendelsohn, R., Dinar, A. (1999) Climate Change, Agriculture, and Developing Countries: Does Adaptation Matter?, The World Bank Research Observer, 14, 277-93. https://doi.org/10.1093/wbro/14.2.277 
Mendelsohn, R. and Williams, L. (2004), Comparing Forecasts of the Global Impacts of Climate Change, 9(4), 315-333.

https://doi.org/10.1023/B:MITI.0000038842.35787.1d

Miketa, A. and Mulder, P. (2005), Energy Economics, 2005, 27(3), 429-453. https://doi.org/10.1016/j.eneco.2005.01.004

Mir, G.U.R. and S. Storm. 2016. Carbon emissions and economic growth: production-based versus consumption-based evidence on decoupling. Institute for New Economic Thinking Working Paper No. 41. New York: INET. https://doi.org/10.2139/ssrn.2772131

Mulder, P. and De Groot, H.L.F., (2007) Sectoral energy- and labourproductivity convergence, Environmental and Resource Economics, 36, 85112. https://doi.org/10.1007/s10640-006-9042-y

Narayan, P.K. and Narayan, S. (2010), Carbon dioxide emissions and economic growth: Panel data evidence from developing countries. Energy Policy, 38(1), 661-666. https://doi.org/10.1016/j.enpol.2009.09.005

Nasir, M. and Rehman, F-U. (2011) Environmental Kuznets curve for carbon emissions in Pakistan: An empirical investigation. Energy Policy, 39, 1857-1864. https://doi.org/10.1016/j.enpol.2011.01.025

Nguyen Van, P. (2005) Distribution Dynamics of CO 2 Emissions," Environmental \& Resource Economics, European Association of Environmental and Resource Economists, 32(4), 495-508. https://doi.org/10.1007/s10640-005-7687-6

O'Brien, K., L. Sygna, and J.E. Haugen 2004. "Vulnerable or Resilient? A Multi-scale Assessment of Climate Impacts and Vulnerability in Norway." Climatic Change $\quad 64 \quad$ (2): 225. https://doi.org/10.1023/B:CLIM.0000024668.70143.80

Omri, A.(2013) CO2 emissions, energy consumption and economic growth nexus in MENA countries: evidence from simultaneous equations models, Energy Econ., 40, 657-664. https://doi.org/10.1016/j.eneco.2013.09.003

PACHAURI, RK; REISINGER, A. (2007), Intergovernmental Panel on Climate Change. Climate Change 2007: Synthesis Report. Contribution of Working Groups I, II and III to the Fourth Assessment 
Report of the Intergovernmental Panel on Climate Change, Geneva, Switzerland.

PAO, Hsiao-Tien; TSAI, Chung-Ming (2011), Modeling and forecasting the CO2 emissions, energy consumption, and economic growth in Brazil, Energy, Vol.36,

2450-2458. https://doi.org/10.1016/j.energy.2011.01.032

PARRY, M.L.; ROSENZWEIG, C.; IGLESIAS, A.; Livermore, M.; FISCHER, G. (2004), Effects of climate change on global food production under SRES emissions and socio-economic scenarios , Global Environmental Change, Vol.14, 53-67. https://doi.org/10.1016/j.gloenvcha.2003.10.008

Parry M.A.J., Madgwick P.J., Carvahlo J.F.C. and Andralojc P.J. 2007) Prospects for increasing photosynthesis by overcoming the limitations of Rubisco. Journal of Agricultural Science, 145, 31- 43. https://doi.org/10.1017/S0021859606006666

PESARAN, M. Hashem, (2004), General diagnostic tests for cross section dependence in panels, University of Cambridge, Faculty of Economics, Cambridge Working Papers in Economics, No. 0435. https://doi.org/10.1016/j.jeconom.2007.05.010

Pesaran, M. H.; Yamagata, T., (2008), Testing Slope Homogeneity in Large Panels, Journal of Econometrics, 142, 50-93.

Raich, J.W. and Potter, C.S., (1995) Global patterns of carbon dioxide emissions from soils. Global Biogeochemical Cycles, 9, 23-36. https://doi.org/10.1029/94GB02723

Shahbaz, M., Zeshan, M., Afza, T., (2012b). Is energy consumption effective to spur economic growth in Pakistan? New evidence from bounds test to level relationships and Granger causality tests. Economic Modelling. 29, 2310-2319. https://doi.org/10.1016/j.econmod.2012.06.027

SOYTAS, Ugur; SARI, Ramazan (2009), Energy consumption, economic growth, and carbon emissions: Challenges faced by an EU candidate 
member, Ecological Economics, Vol.68, 1667-1675. https://doi.org/10.1016/j.ecolecon.2007.06.014

STOLYAROVA, Elena, (2009) Carbon Dioxide Emissions, Economic Growth and Energy Mix: Empirical Evidence From 93 Countries, Climate Economics Chair Paris-Dauphine University.

Strazicich, M.C., List, J.A., (2003) Are CO2 emission levels converging among industrial countries? Environ. Resour. Econ. 24, 263-271.

Swamy, P.A.V.B., (1970) Efficient Inference in a Random Coefficient Regression Model, Econometrica, 38(2), 311-23. https://doi.org/10.2307/1913012

TIWARI, Aviral Kumar (2011) Energy Consumption, CO2 Emissions and Economic Growth: A Revisit of The Evidence from India, Applied Econometrics and International Development, Vol.11, No.2, 165-189. https://doi.org/10.2478/v10033-011-0019-6

TUMLIN, J. (2012), Sustainable Transportation Planning: Tools for Creating Vibrant, Healthy, and Resilient Communities John Wiley \& Sons, 2012.

WANG, Shaojian; Lİ, Qiuying; FANG, Chuanglin; ZHOU, Chunshan, (2016), The relationship between economic growth, energy consumption, and CO2 emissions: Empirical evidence from China, Science of the Total Environment, Vol.542, 360-371. https://doi.org/10.1016/j.scitotenv.2015.10.027

Xue, Y., You, J. and Shao, L. 2014. Understanding socio-technical barriers to sustainable mobility - insights from Demonstration Program of EVs in China. Problems of Sustainable Development. 9(1), 29-36.

ZHANG, Xing-Ping; CHENG, Xiao-Mei (2009), Energy consumption, carbon emissions, and economic growth in China, Ecological Economics, Vol.63, 2706-2712. https://doi.org/10.1016/j.ecolecon.2009.05.011 
